\title{
Evaluation of cassava foliage as a protein supplement for sheep
}

\author{
J.K. Alli-Balogun, C.A.M. Lakpini, J.P. Alawa, A. Mohammed and J.A. Nwanta \\ College of Agriculture and Animal Science, Ahmadu Bello University, Zaria, Nigeria
}

\begin{abstract}
Three trials were conducted to evaluate the potential of cassava (Manihot esculenta) foliage (leaves and petioles) as a protein supplement for sheep. In the first trial, nylon bag degradability of cassava foliage was studied. Proximate analysis of cassava foliage was conducted before and after the incubation. Rumen Ammonia Concentration (RAC) and $\mathrm{pH}$ were determined at 0,4 and 8 hours after feeding cassava foliage diet (30\%). Proximate composition of sundried cassava foliage was (\%) DM 91.25, CP 18.55, NDF, 31.41, ADF, 29.2, EE, 6.6, Ash, 12.95. Nylon-bag dry matter disappearance (DMD) increased significantly $(P<0.05)$ from $15.75 \%$ to $75.5 \%$ RAC values increased significantly from $8.20 \mathrm{mg} \mathrm{NH} / 100 \mathrm{ml}$ at zero hour to $11.41 \mathrm{mg} \mathrm{NH}_{3} / 100 \mathrm{ml}$ at 8 hours post feeding. Rumen fluid pH was not significantly changed by the $30 \%$ cassava foliage diet. In the second trial lasting 56 days, twenty-eight Yankasa/WAD yearling rams of initial average weight of $18 \mathrm{~kg}$ were balanced for weight and randomly allotted to seven treatments. All rams except those on control diet were fed cassava foliage or groundnut haulms or both at $1.0 \%$ or $1.5 \%$ of body weight (BW) as supplements to a basal diet of Gamba hay. Feeding Gamba hay alone (control) resulted in weight loss ($30.5 \mathrm{~g} /$ day) but with cassava foliage or groundmut haulms supplementation at $1.0 \% \mathrm{BW}$, significantly higher gains of 39.2 and $44.6 \mathrm{~g} /$ day were achieved respectively. At $1.5 \%$ BW level of supplementation with cassava foliage or groundnut haulms higher weight gains of 41.2 and $51.7 \mathrm{~g} /$ day were achieved while feeding the (50.50) combined supplements at 1.0 and $1.50 \% \mathrm{BW}$ resulted in live weight gains of 65.1 and $69.3 \mathrm{~g} /$ day respectively. The third trial consisted of a four week grazing trial followed by a metabolic study. Twenty-one Yankasa/WAD yearling rams were randomly allotted to seven treatments and were balanced for live weight. All rams were allowed to graze standing digitaria hay as basal diet, except the rams on control diet. Those on treatment were fed cassava foliage or groundnut haulms or a (50:50) combination of both at $0.5 \%$ and $1.0 \%(B W$. The metabolic study consisted of a seven day adjustment period and a seven day total collection period. There was no significant difference $(P>0.05)$ in the live weight gains of rams on the control diet compared with those supplemented except for those supplemented with cassava foliage and groundnut haulms combined at $1 \%$ level where the weight gain was significantly higher $(p<0.05)$. Feed intake was not significantly $(P>0.05)$ affected by feeding either supplement. Supplementing digitaria hay with cassava foliage at both $0.5 \%$ and $1.0 \% \mathrm{BW}$ did not significantly increase the nitrogen retention values, but groundnut haulms supplemented at $1.0 \% \mathrm{BW}$ significantly $(P<0.05)$ increased the nitrogen retention values.
\end{abstract}

Keywords: Cassava foliage, nylon-bag degradation, rumen-ammonia, concentration incubation, dry matter disappearance, nitrogen retention. 


\section{Alli-Balogun, Lakpini, Alawa, Mohammed and Nwanta}

\section{Introduction}

According to FAO (1986) figures, Nigerians intake of animal protein is $15 \mathrm{~g}$ per day, which is below the recommended minimum level of $35 \mathrm{~g}$ per day. The main reason for this poor intake of animal protein is poor livestock productivity, which is as a result of poor nutrition, breeding. management and disease control. Of these factors, nutrition appears to be most important because the gains of selective breeding, proper management and disease control can only be realized with an adequate plane of nutrition.

Recently, most work has concentrated on utilization of crop residues and pasture species because of their availability during the long dry season. The major prohlem with crop residues as a feedstuff is that of poor efficiency of utilization probably as a result of its generally high fibre and low soluble carbohydrates content (Dixon and Egah, 1987). Various methods of improving the efficiency of utilization focuses on enhancing rumen microbial fermentation, either by physical treatment (Mohammed et al., 1987) or by chemical treatment (Garmo, 1981, Nour, 1997), Unfortunately, these methods are not popular because of high cost or unavailability of inputs. A more practical approach to increasing the efficiency of utilization of crop residues is the addition of protein or non-protein nitrogen to the diets consisting of crop residues on poor quality hay (Bezkorowajinyi et al., 1986, Ndloyu and Buchanan-Smith, 1985).

The case for cassava foliage as protcin supplement rest not only on the relatively high crude protein content but also on its availability in most parts of the country throughout the year. These studies were theretione conducted to evaluate cassava foliage as a protein supplement for sheep, in comparison with groundnut haulms which is more popularly used.

\section{Materials and Methods}

\section{Gemeral feedstuff preparation and Animal management}

The study was conducted at Shika, Kaduna State on latitude $11^{\circ} \mathrm{N}$ in the Guinca Savannah zone of Northern Nigeria and the climate has been described by Buvanendran et al.,(1981). Cassava foliage used were of the local sweet variety grown afround Shika. They were harvested fresh and then sundried for seven days until the leaves and petioles wcre brittle and thoroughly dried. The groundnut haulms fed were purchased at the local market, but care was taken to ensure that they had high quality of dried green leaves and were not mouldy. Gamba hay utilized was harvested and baled from NAPRI pastures the previous year. Supplements were offered 7.30a.m. and after complete consumption the basal diets were then offered.

Rams utilized were crosses of Yankasa/WAD shocp. They were quarantined for thirty days during which they were dewormed and bathed in acaricide solution (Iriatix). Rams were housed in individual pens with concrete floxors measuring $3.0 \mathrm{~m} \times 1.5 \mathrm{~m}$ with open-sided walls. The stall fed rams were allowed out into holding pens twice weekly while the individual pens were washed and disinfoctcd. All rams were provided salt licks.

Trial 1: Two Yankasa rumen-fistulated ewes of average weight of $20 \mathrm{~kg}$ and aged 1.5 years were used in this study. The technique of rumen fistulation used was a modification of the single abdominal wall incision method as described by Lufadeju (1988a). Three wecks before commencement of the experiment, the ewes were daily given a supplement containing $30 \%$ cassava foliage after which the cwes were allowed to graze Brachiaria pastures. Sundried cassava foliage (leaves and petioles) was ground using a laboratory hammer mill fittod with a $2.5 \mathrm{~mm}$ screen mesh. Approximately $2.5-3.5 \mathrm{~g}$ of cassava foliage samples were weighed into 10 x $8 \mathrm{~cm}$ nylon-bags with $20-40$ micro mesh size. The nylon hags were sealed and attached by means of clastic rubber bands to a $40 \mathrm{~cm}$ flexible rubher tube attached to the cannula cover with a nylon string. Duplicated nylon-bags containing samples of cassava foliage were inserted in the rumen of the ewes for $0,8,16$, $24,48,72$ and 96 hours. Upon withdrawal the bugs were washed under running water until the water wats clear. The bags were then dried at $70^{\circ} \mathrm{C}$ for twenty-four hours and weighed 


\section{Cassava foliage as protein supplement for sheep}

marting to procedure described by Mehrez and irs: (1977).

kmen Ammonia Concentration (RAC) was xerenined at 0.4 and 8 hours post feeding from men fluid samples by mixing with equal aime of $0.1 \mathrm{NH}_{2} \mathrm{SO}_{4}$ and immediately stored I a treezer. RAC values were obtained by steam ss:lation collected with acid (Whitehead, 67 1. Rumen fluid pII was also determined sing Philips digital pH meter (model 9409). Thimate analysis on cassava foliage was inducted before and after incubation.

Trial 2: Twenty eight Yankasa/WAI) rams soxses) of initial average $18 \mathrm{~kg}$ and aged 1.5 ears were used in this study. They were allotted Ito seven groups of four rams in each group ralanced for weight then randomly assigned into Iifferent treatment groups (Table 2.1). all rams zcept those on control diet were fed cassava thage or groundnut haulms or a $(50: 50)$ zmbination of both as supplements at $1.0 \mathrm{or}$ $1.5 \%$ BW to a basal diet of Gamba hay. All rams were stall-fed. Supplements were offered at 7.30a.m. and after complete consumption, Gamba hay was offered in a manner to allow $15 \%$ rejection. Animals were weighed weekly and the trial lasted fifty-six days. Body condition scoring was conducted by two individual scorers using visual assessment. The results were analysed statistically using the principle of analysis of variance (ANOVA) Snedecor and Cochran (1967).

Trial 3: $\Lambda$ grazing trial lasting four weeks was conducted with twenty-one Yankasa/WAD rams (crosses) of average initial weight of $29 \mathrm{~kg}$ and aged 1.5 years. They were allocated into seven groups of three rams each and the group balanced for live weight before they were randomly allocated to different treatments. All rams grazed standing digitaria hay and except those on control diet, all rams were fed either cassava foliage or groundmut haulms or a (50:50) combination of both as supplements at $0.5 \%$ or $1.0 \%$ BW (Table 7). The supplements were offered at 7.30a.m. and after complete consumption were allowed to graze digitaria pastures. Live weight gains were taken wockly. Aflerwards a metabolic trial consisting of seven days adjustment period and seven days total collection period was conducted. Rams were stall-fed digitaria hay plus supplements in pens measuring $1.0 \times 2.0 \mathrm{~m}$ with concrete floors and were on a raised platform with a container below it. $\Lambda$ tine net trapped faecal droppings while allowing urine flow into the container below. Total feed intake was measured while urine and faeces output were collected sumpled and analysed for nitrogen, according to A.O.A.C (1986) procedure. The results were analysed statistically using principle of Analysis of Variance (Snedecor and Cochran, 1967).

\section{Results}

Proximate composition of cassava foliage and other feedstuffs used are shown in Table 1.

Table 1 Proximate analysis of feedstuffs used

\begin{tabular}{llllllll}
\hline Feedstuff & DM\% & CP\% & NDF & ADF & ASH & I.IGNIN & $48 H R$ \\
\hline Cassava foliage & 91.25 & $\mathbf{1 8 . 5 5}$ & 31.41 & 29.3 & 12.93 & 14.14 & 70.59 \\
Groundnut haulms & $\mathbf{8 7 . 0 5}$ & 12.87 & 35.89 & 31.49 & 11.41 & 6.38 & \\
Digitaria hay & 87.6 & 5.7 & 76.99 & 52.32 & 8.3 & - & \\
Gamba hay & 90.3 & 3.43 & 76.4 & 56.2 & 5.4 & - & 45.8 \\
\hline
\end{tabular}

T.ufadeju (1988a)

Nylon-bags DMD ( Table 2) significantly ( $\mathrm{P}<0.05$ ) increased from $15.76 \%$ at zero hours to $70.59 \%$ at fourty-cight hours but further increases were not significant ( $\mathrm{P}>0.05)$ from forty-eight to ninety-six hours ( $70.59-75.5 \%)$. 


\section{Alli-Balogun, Lakpini, Alawa, Mohammed and Nwanta}

\section{Introduction}

According to FAO (1986) figures, Nigerians intake of animal protein is $15 \mathrm{~g}$ per day, which is below the recommended minimum level of $35 \mathrm{~g}$ per day. The main reason for this poor intake of animal protein is poor livestock productivity, which is as a result of poor nutrition, breeding. management and disease control. Of these factors, nutrition appears to be most important because the gains of selective breeding, proper management and disease control can only bc realized with an adequate plane of nutrition.

Recently, most work has concentrated on utilization of crop residues and pasture species because of their availability during the long dry season. The major problem with crop residues as a feedstuff is that of poor efficiency of utilization probably as a result of its generally high fibre and low soluhle carbohydrates content (Dixon and Egah, 1987), Various methods of improving the efficiency of utilization focuses on enhancing rumen microbial fermentation, either by physical treatment (Mohammed et al., 1987) or by chemical treatment (Garmo, 1981, Nour, 1997). Unfortunately, these methods are not popular because of high cosi or unavarlability of inputs. A morc practical approach to increasing the efficiency of utilization of crop residues is the addition of protein or non-protein nitrogen to the diets consisting of crop residues on poor quality hay (Bezkorowajinyi et al., 1986, Ndloyu and Huchanan-Smith, 1985).

The case for cassava foliage as protein supplement rest not only on the relatively high crude protein content but also on its availability in most parts of the country throughout the year. These studies were therefore conducted to evaluate cassava foliage as a protein supplement for sheep, in comparison with groundnut haulms which is more popularly used.

\section{Materials and Methods}

General feedstuff prepanation and Animal management

The study was conducted at Shika, Kaduna State in latitude $11^{\circ} \mathrm{N}$ in the Guinea Savannah zone of Northern Nigeria and the climate has bern described by Buvanendran et al,,(1981). Cassava foliage used were of the local sweet variety grown a around Shika. They were harvested fresh and then sundried for seven days until the leaves and petioles were brittle and thoroughly dried. The groundnut haulms fed were purchased at the local market, but care was taken to ensure that they had high quality of dried green leaves and were not mouldy. Gamba hay utilized was harvested and baled from NAPRI pastures the previous year. Supplements were oflered 7.30a.m. and after complete consumption the basal diets were then offered.

Rams utilized were crosses of Yankasa/WAD sheep. They were quarantined for thirty days during which they were dewormed and bathed in acaricide solution (Triatix), Rams were housed in individual pens with concrete floors measuring $3.0 \mathrm{~m} \times 1.5 \mathrm{~m}$ with open-sided walls, The stall fed rams were allowed cut into holding pens twice wockly while the individual pens were washed and disinfected. All rams were provided silt licks.

Trial 1: Two Yankasa rumen-fistulated ewes of average weight of $20 \mathrm{~kg}$ and aged 1.5 years were uscd in this study. The technique of rumen fistulation used was a modification of the singlc abdominal wall incision method as described by Lufadeju (1988a). Three wceks before commencement of the experiment, the ewes were daily given a supplement containing 30\% cassava foliage after which the ewes were allowed to graze Brachiaria pastures. Sundried cassava foliage (leaves and petioles) was ground using a laboratory hammer mill fitted with a $2.5 \mathrm{~mm}$ screen mesh. Approximately $2.5-3.5 \mathrm{~g}$ of cassava foliage samples were weighed into 10 $\times 8 \mathrm{~cm}$ nylon-bags with $20-40$ micro mesh size. The mylon bags were sealed and attached by means of elastic rubbcr bands to a $40 \mathrm{~cm}$ flexible rubber tube attached to the cannula cover with a nylon string. Duplicated nylon-bags containing samples of cassava foliage were inserted in the rumen of the ewes for $0,8,16$, $24,48,72$ and 96 hours. Upon withdrawal the bags were washed under running water until the water was clear. The bays were then dried at $70^{\circ} \mathrm{C}$ for twenty-four hours and weighed 


\section{Cassava foliage as protein supplement for sheep}

scoording to procedure described by Mehrez and Orskov (1977).

Rumen Ammonia Concentration (RAC) was setermined at 0.4 and 8 hours post feeding from rumen fluid samples by mixing with equal volume of $0.1 \mathrm{NH}_{2} \mathrm{SO}_{4}$ and immediately stored in a freezer. RAC values were obtained by steam distillation collected with acid (Whitehead, 1967). Rumen fluid $\mathrm{pH}$ was also determined using Philips digital pH meter (model 9409). Proximate analysis on cassiva foliage was conducted before and afler incubation.

Trial 2: Twenty eight Yankasa/WAD rams (crosses) of initial average $18 \mathrm{~kg}$ and aged 1.5 years were used in this study. They were allotted into seven groups of four rams in each group balanced for weight then randomly assigned into different treatment groups (Table 2,1). all rams except those on control diet were fed cassava foliage or groundnut haulms or a (50:50) combination of both as supplements at 1.0 or $1.5 \%$ BW to a basal diet of Gamba hay. All rams were stall-fed. Supplements were offered at $7.30 \mathrm{a} . \mathrm{m}$. and after complete consumption, Gamba hay was offered in a manner to allow $15 \%$ rejection. Animals were weighed weckly and the trial lasted fifty-six days. Body condition scoring was conductod by two individual scorers using visual assessment. The results werc analysed statistically using the principle of analysis of variance (ANOVA) Snedecor and Cochran (1967).

Trial 3: A grazing trial lasting four weeks was conducted with twenty-one Yankasa/WAD rams (crosses) of average initial weight of $29 \mathrm{~kg}$ and aged 1.5 years. They were allocated into seven groups of three rams each and the group balanced for live weight before they were randomly allocated to different treatments. All rams grased standing digitaria hay and except those on control diet, all rams were fed either crssava foliage or groundnut haulms or a (50:50) combination of both as supplements at $0.5 \%$ or $1.0 \%$ BW (Table 7). The supplements were offered at $7.30 \mathrm{a} . \mathrm{m}$. and after complete consumption were allowed to graze digitaria pastures. Live weight gains were taken weekly. Afterwards a metabolic trial consisting of seven days adjustment period and seven days total collection period was conducted. Rams were stall-fed digitaria hay plus supplements in pens measuring $1.0 \times 2.0 \mathrm{~m}$ with concrete floors and were on a raised platform with a container bciow it. A fine net trapped faccal droppings while allowing urine flow into the container below. Total feed intake was measured while urine and facoes output were collected sampled and analysed for nitrogen, according to A.O.A.C (1986) procedure. The results were analysed statistically using principle of Analysis of Variance (Snedecor and Cochran, 1967).

\section{Results}

Proximate composition of cassava foliage and other feedstuffs used are shown in Table 1.

Table 1 Proximate analysis of feedstuffs used

\begin{tabular}{llllllll}
\hline Feodstuff & DM\% & CP\% & NDF & ADF & ASH & I.IGNN & 48HR \\
\hline Cassava foliage & 91.25 & 18.55 & 31.41 & 29.3 & 12.93 & 14.14 & 70.59 \\
Groundnut hauims & $\mathbf{8 7 . 0 5}$ & 12.87 & 35.89 & 31.49 & 11.41 & 6.38 & \\
Digitaria hay & 87.6 & 5.7 & 76.99 & 52.32 & 8.3 & - & \\
Gamba hay & 90.3 & 3.43 & 76.4 & 56.2 & 5.4 & - & 45.8 \\
\hline \hline
\end{tabular}

Lufadeju (1988a)

Nylon-bags DMD ( Table 2) significantly ( $\mathrm{P}<0,05$ ) increased from $15.76 \%$ at zero hours to $70.59 \%$ at fourty-eight hours but further increases were not significant $(P>0.05)$ from forty-eight to ninety-six hours $(70.59-75.5 \%)$. 


\section{Alli-Balogun, Lakpini, Alawa, Mohammed and Nwanta}

Table 2 Mean dry matter disappearance of cassana foliage

\begin{tabular}{llll}
\hline Time Hours & DMD & + & SE \\
\hline 0 & $15.74^{\mathrm{a}}$ & + & 0.176 \\
8 & $26.87^{\mathrm{a}}$ & + & 0.925 \\
16 & $60.09^{\mathrm{e}}$ & + & 3.532 \\
24 & $68.35^{\mathrm{d}}$ & + & 1.387 \\
48 & $70.59^{\mathrm{e}}$ & + & 0.846 \\
72 & $74.28^{\mathrm{e}}$ & + & 0.487 \\
96 & $75.57^{\mathrm{a}}$ & + & 1.0881 \\
\hline
\end{tabular}

Means in the same column with different superseripts differ significantly $(\mathrm{P}<0.05)$

Table 3 Rumen ammonia concentration and $\mathrm{pH}$ of numen fluid

\begin{tabular}{|c|c|c|c|}
\hline Hours (Post feeding) & $\mathrm{RAC} \mathrm{mg} \mathrm{NH}_{3} / 100 \mathrm{ml}$ & $+\mathrm{SE}$ & $\mathrm{pH}$ \\
\hline $\begin{array}{l}0 \\
4 \\
8\end{array}$ & $\begin{array}{l}8.193 \\
17.5108 \\
11.406\end{array}$ & $\begin{array}{l}0.2409 \\
0.4016 \\
0.8032\end{array}$ & $\begin{array}{l}7.37 \\
6.425 \\
6.385\end{array}$ \\
\hline
\end{tabular}

RAC values (Table 3 ) increased significantly (P<0.05) from $8.20 \mathrm{mg} \mathrm{NH3} / 100 \mathrm{ml}$ at zero hours to $17.52 \mathrm{mg} \mathrm{NH} / 100 \mathrm{ml}$ at 4 hours and decreased to $11.41 \mathrm{mg} \mathrm{NH}_{3} / 100 \mathrm{ml}$ at eight hours post feeding cassava foliage diet. The $\mathrm{pH}$ of rumen fluid at zero hours was 6.38 . Proximate analysis of sample residue for NDF, ADF and crude protein were significantly (P-0.05) higher than in the original sample (Table 4) results of $1 \mathrm{MD} \%$ were fitted into an exponential equation of the form.

Table 4 Crude protein NDF and ADF contents of cassava foliage sample residue

\begin{tabular}{llll}
\hline Incubation hours & $\mathrm{NDF}$ & $\mathrm{NDF}$ & $\mathrm{CP}$ \\
\hline 8 & 74.82 & 53.43 & 24.84 \\
16 & 74.15 & 65.47 & 26.42 \\
24 & 74.057 & 66.36 & 21.70 \\
48 & 70.63 & 61.92 & 17.53 \\
72 & 70.13 & 61.36 & 18.51 \\
96 & 72.33 & 62.72 & 18.83 \\
\hline \hline
\end{tabular}

$\mathrm{P}=\mathrm{a}+\mathrm{b}\left(1-\mathrm{c}^{-\mathrm{e}}\right)$ (Orskov and MciDonald, 1979)

Where:

P $\quad$ = Degradation taking place at time $\mathrm{t}=0226809$

a $\quad=$ Proportion of food rapidly degraded (intercept) $=15.75$

b $\quad=$ Proportion of feed gradually degraded $=59.83$

$\mathrm{c}$
$(\mathrm{a}+\mathrm{b})=$ Rsymptote

In trial 2 live weight gains are shown in Table 5. Rams fed Gamba hay alone lost weight (-30g/day) but with $1.0 \%$ of BW cassava foliage or groundnut haulms supplementation, 


\section{Cassava foliage as protein supplement for sheep}

significantly $(\mathrm{P}<0.05)$ higher gains $(39.2$ or 45.2g/day respectively) were obtained. Daily live weight gains of rams on cassava foliage at 1.0 and $1.5 \%$ BW supplementation were similar to that of rams fod groundnut haulms at $1.0 \mathrm{BW}$.
Rams fed the combined supplements at 1.0 and $1.5 \%$ had similar weight gains but were significantly $(\mathrm{P}<0.05)$ higher than all other groups.

Table 5 Live weight gains

\begin{tabular}{lllllllll}
\hline & C & CF & CF & GnH & GnH & CF & GnH & \\
\multicolumn{1}{c}{$\mathrm{S}$} & S & T2 & T3 & T4 & T5 & T6 & T7 & \\
\hline Mean initial weight $(\mathrm{kg})$ & 18.25 & 17.6 & 17.3 & 18.37 & 17.75 & 18.13 & 17.87 & \pm 0.144 \\
Mean final weight $(\mathrm{kg})$ & 16.57 & 19.79 & 20.9 & 20.9 & 20.64 & 21.77 & 21.75 & \pm 0.677 \\
Mean weight gains $\mathrm{g} /$ day & $-30.5^{\mathrm{a}}$ & $39.2^{\mathrm{b}}$ & $44.6^{\mathrm{bo}}$ & $45.2^{\mathrm{be}}$ & $51.7^{\mathrm{e}}$ & $65.1^{\mathrm{d}}$ & $69.3^{\mathrm{d}}$ & \pm 12.6 \\
\hline \hline
\end{tabular}

Means in the same row with different superscripts differ significantly $(\mathrm{P}<0.05)$

C $=$ Control

CF - Cassava foliage

GinH = Groundnut Haulms

S - Level of supplement fed as $\%$ of body weight

Table 6 Bady condition score

\begin{tabular}{lccccccc}
\hline & T1 & T2 & T3 & T4 & T5 & T6 & T7 \\
\hline $\begin{array}{l}\text { Initial body } \\
\text { Condition score }\end{array}$ & 3.0 & 3.0 & 3.0 & 3.0 & 3.0 & 3.0 & 3.0 \\
$\begin{array}{l}\text { Final body } \\
\text { Condition score }\end{array}$ & 1.0 & 2.0 & 3.4 & 3.4 & 3.8 & 4.0 & 4.0 \\
\hline \hline
\end{tabular}

Subjective scoring on a scale of $1=$ poor, $2=$ moderate, $3=$ good

In trial 3 results of the four weeks grazing trial (Table 7) showed that rams fed digitaria hay alone (control), groundnut haulms at $0.5 \% \mathrm{BW}$, or cassava foliage at $0.5 \%$ or $1.0 \% \mathrm{BW}$ exhibited no significant difference $(\mathrm{P}>0.05)$ in their weight gains which were significantly $(\mathrm{P}<0.05)$ lower than in other groups. Rams fed combined supplements at $1.0 \% \mathrm{BW}$ had significantly ( $\mathrm{P}<0.05)$ higher weight gains than any other group of rams. 


\section{Alli-Balogun, Lakpini, Alawa, Mohammed and Nwanta}

Table 7 Live weight gains and nitrogen metabolism

\begin{tabular}{lllllllll}
\hline & $\mathrm{C}$ & $\mathrm{CF}$ & $\mathrm{CF}$ & $\mathrm{GnH}$ & $\mathrm{GnH}$ & $\mathrm{CF}$ & $\mathrm{GnH}$ & \\
& $\mathrm{T} 1$ & $\mathrm{~T} 2$ & $\mathrm{~T} 3$ & $\mathrm{~T} 4$ & $\mathrm{~T} 5$ & $\mathrm{~T} 6$ & $\mathrm{~T} 7$ & \\
\multicolumn{1}{c}{$\mathrm{S}$} & $0 \%$ & $0.5 \%$ & $0.5 \%$ & $1.0 \%$ & $1.0 \%$ & $0.5 \%$ & $1.0 \%$ & $\mathrm{SEM}$ \\
\hline DM intake g/day & 786.4 & 789.66 & 894.91 & 863.95 & 912.98 & 807.3 & 792.55 & \pm 20.4 \\
Mean weight gain g/day & $53.57^{\mathrm{a}}$ & $53.37^{\mathrm{a}}$ & $62.49^{\mathrm{ab}}$ & $59.52^{\mathrm{a}}$ & $89.29^{\mathrm{ab}}$ & $83.23^{\mathrm{ab}}$ & $95.23^{\mathrm{b}}$ & \pm 6.45 \\
$\begin{array}{l}\text { Digestibility } \\
\text { N. Metabolism }\end{array}$ & $67.8^{\mathrm{a}}$ & $68.63^{\mathrm{a}}$ & $77.64^{\mathrm{ab}}$ & $69.83^{\mathrm{ab}}$ & $78.3^{\mathrm{b}}$ & $78.6^{\mathrm{b}}$ & $81.06^{\mathrm{bc}}$ & \pm 2.10 \\
N intake g/day & 7.17 & 9.04 & 8.98 & 11.21 & 10.14 & 8.79 & 9.57 & \pm 0.488 \\
Faecal N g/day & 3.98 & 4.44 & 4.51 & 5.72 & 3.11 & 2.63 & 2.65 & \pm 0.430 \\
Urine N g/day & 0.86 & 0.93 & 0.42 & 0.86 & 0.63 & 0.75 & 0.62 & \pm 0.0676 \\
Total N exc. g/day & 4.84 & 5.37 & 4.93 & 6.58 & 3.74 & 3.38 & 3.27 & \pm 0.0676 \\
N Retained g/day & $2.33^{\mathrm{a}}$ & $3.67^{\mathrm{ab}}$ & $4.05^{\mathrm{ab}}$ & $4.63^{\mathrm{bc}}$ & $6.70^{\mathrm{c}}$ & $5.14^{\mathrm{bc}}$ & $6.30^{\mathrm{c}}$ & \pm 0.454 \\
\% N Retained of N & & & & & & & & \\
intake & $32.50^{\mathrm{a}}$ & $40.6^{\mathrm{ab}}$ & $45.10^{\mathrm{ab}}$ & $41.3^{\mathrm{ab}}$ & $64.17^{\mathrm{c}}$ & $61.54^{\mathrm{c}}$ & $65.83^{\mathrm{c}}$ & \pm 5.16 \\
\hline
\end{tabular}

Means in the same row with different superscripts letter differ significantly $(\mathrm{P}<0.05)$

$\mathrm{CF} \quad=$ Cassava foliage

$\mathrm{GnH}=$ Groundnut Haulms

$\mathrm{S} \quad=$ Level of supplement fed as $\%$ of body weight

The addition of cassava foliage, groundnut haulms or a combination of both at $0.5 \%$ or $1.0 \% \mathrm{BW}$ level of supplement did not significantly change the total dry matter intake. Rams fed the control diet, $0.5 \%$ groundnut haulms or $0.5 \%$ or $1.0 \%$ cassava foliage supplement had similar daily nitrogen retention values which were significantly $(\mathrm{P}<0.05 \%)$ lower than the daily nitrogen retention values of others (Table 7). Also rams on the control group, groundnut haulms at $0.5 \% \mathrm{BW}$ or cassava foliage at $0.5 \%$ and $1.0 \% \mathrm{BW}$ levels of supplementation, had similar approximate digestion coefficient values which were significantly lower than those of other groups.

\section{Discussion}

Smith et al.,(1988) reported degradability of cassava foliage (leaves) as being $84.3 \%$ within forty-eight hours. This differs with that obtained in trial $1(70.59 \%)$ within the same time. The difference in $\mathrm{DMD} \%$ values might be due to presence of petiole ( which consists of more structural vascular bundles) in the cassava foliage used for this trial. Abate (1991) observed that fibrous materials are less soluble because of the dominance of structural over soluble carbohydrates in the cell wall. High rate of $\mathrm{DMD} \%$ suggests that cassava foliage would constitute low rumen load thus optimizing voluntary intake. Also knowledge of the degradation characteristic of cassava foliage would aid combining it with carbohydrate sources of similar degradation characteristic thus synchronizing the release of nitrogen and energy compounds which facilitate microbial protein synthesis. Leng and Nolan (1984) reported optimum rumen ammonia concentration ranging $5-20 \mathrm{mg} \mathrm{NH}_{3} / 100 \mathrm{ml}$. RAC at four hours post feeding was $17 \mathrm{mg} \mathrm{NH}_{3} / 100 \mathrm{ml}$ which is well within the range cited. Although RAC values at eight hours was significantly $(\mathrm{P}<0.05)$, lower this might be due to the $\mathrm{NH}_{3}$ diffusion out of the rumen or that is being utilized in microbial protein synthesis. The $\mathrm{pH}$ at four post feeding was 6.42 , which is within range reported by Niovu (1992) (6.5 - 6.8) being optimal for maximum celluloysis. The difference in $\mathrm{pH}$ at 


\section{Cassava foliage as protein supplement for sheep}

$=$ : sours and fours post feeding might be due $\tau$ resence of maize grain in the diet. Higher Lf ADF values of the sample after meare shows that the soluble portion of D-5i stiage had been degraded leaving tes restue which had higher NDF and ADF ans $\mathrm{As}$ higher crude protein values of the - ifa incubation might be due to Dere if rumen microbes that were not re the sample.

ance casava foliage to rams in trial 2 was re revent weight loss although it showed $30 x$ telly weight gains. This is most likely due c me tigh rate of degradation of cassava foliage 7.51 , within forty-eight hours compared to the s rate of Gamba hay degradation (45.8\%) -riveju 1988b) within the same time. This -xid result in low availability of glycogenic accounds necessary to enable the rumen murobes utilize the nitrogen liberated from zesara foliage. Rams fed groundnut haulms had mgher gains most likely due to the slower rate of xestatation as evidence from the higher crude fire content (32.8\%) (Adu and Lapkini, 1983) zrppared to that of cassava foliage (4.8 $: 2.8 \%$ ) Smith 1992). This might have resulted in 1 etrer synchronized release of nitrogen and zachydrate. Furthermore, Silver and Orskov \$85) reported legume crop residues ability to pxide fermentation energy to the rumen in the irm of available cellulose and hemicellulose which stimulate fibre digestion. This could explain the better responses in live weight gain of rams fed the combined supplements.

in trial 3 similar live weight gains by rams fed the control diet ( no supplement) and rams fed dither of the supplement at $0.5 \%$ BW suggests that $0.5 \% \mathrm{BW}$ level of supplementation is too small to effectively stimulate additional microbial protein synthesis. Rams on $1 \%$ level of groundnut haulms supplemenation gave higher gains than rams on cassava foliage. This could be attributed to the rapid rate of degradation of cassava foliage compared to groundnut haulms. Most of the cassava foliage generated nitrogen would likely be under utilized due to slow rate of glycogenic compounds from digitaria hay. But for groundnut haulms the slower rate of degradation might have resulted in a better synchronized release of glycogenic compound and nitrogen thus enhancing microbial protein synthesis in the rams. The combined supplcments at either levels of supplementation performed better than either of the supplements alone. This is most likely due to presence of additional crude protein from cassava foliage and groundnut haulms plus additional fermentable energy from groundnut haulms.

Addition of either supplement or their combination did not result in a significant change in dry matter intake. Higher crude fibre contents of digitaria hay may have resulted in it having relatively slower rates of degradation compared to cassava foliage or groundnut haulms. Possibly both supplements constitute low rumen load due to their relatively faster degradation. Moran et al.(1983) described an idcal supplement as one, which maintains or increases the intake of the basal diet rather than one which substitutes for it.

Additional nitrogen from cassava foliage as shown in Table 7 was poorly utilized as evidenced by the high levels of faecal and urinary nitrogen. Karve (1973) reported the retention and utilization of dietary nitrogen being influenced by the type and quality of carbohydrate present. Most likely, in the absence of readily fermentable energy sources which enhance microbial utilization of nitrogen, most of the additional nitrogen may have simply boen absorbed through the walls of the rumen into the blood system from where it may have been eventually passed out of the body with urine and faeces or recycled through saliva back to the rumen where it influences digestion rate of cellulose (Kenedy and Milligan, 1988).

\section{Conclusion}

From this study, it is evident that cassava foliage has high degradability and it generates adequate amounts of nitrogen in the rumen. Feeding cassava foliage or groundnut haulms as a supplement to Gamba hay or digitaria hay improved weight gains but the combination of both supplements gave best results. 


\section{Alli-Balogun, Lakpini, Alawa, Mohammed and Nwanta}

Furthermore, cassava foliage can be used to completely replace groundnut haulms as a protein supplement. The high amount of faecal and urinary nitrogen voided is evidence of poor utilization of additional nitrogen generated from cassava foliage. It is expected that with readily fermentable energy sources cassava foliage supplementation would elicit better responses in terms of live weight gain.

\section{References}

Abate, A. and Kiflewahid, B. 1991. Using of nylon bag technique in determining the complementary of feedstuff for dairy cattle rations. In the complementarity of feed resources for animal production in Africa. Proceeding of the joint feed resources networks, workshop held in Garborone Botswana AFRN $4-8^{\text {th }}$ March, 1994. pp $225-232$.

Adu, I.F. and Lakpini, C.A.M. 1983. Effect of feeding chopped and unchopped groundnut haulms (Harawa) on nutrient utilization and production of some rumen metabolites in Yankasa rams. Invited paper presented at $9^{\text {th }}$ Annual Conference of Nigeria Society of Animal Prochuction.

A.O.A.C. 1986. Official methods of analysis. Association of official analytical chemists. $13^{\text {th }}$ edition.
Bezkorowajnyj, J.P, Wanapat, M. and Phongphairoj, S. 1986. Supplementaion of cassava leaf and chips to rice straw based diets for growing cattle. In rice straw and related feeds in ruminant rations. $\mathrm{Pp}$ 225 - 260 (ed. Ibrahim, M.N.M and Sehiere, J.B) (Straw utilization project Srilanks).

Buvanendran, V., Olayiwole, M.B., Pietrowska, K.I. and Oyejola, B.A. 1981. A comparison of milk production traits in Freesign X White Fulani crossbred cattle Animal production. 32:165 - 170.

Dixon, R.M. and Egah, A.R. 1987. Strategies for optimizing use of fibrous crop residues as animal feeds. In ruminant feeding system utilizing fibrous agricultural residues 1987. International development program of Australian Universities and Colleges.

FAO 1986. production year book (FAO Rome) p 8.

Garmo, T.H. 1981. Ensiling of alkali treated straw in the utilization of low quality roughages in Africa. Proceedings of workshop held in Arusha Tanzania (Ed Kategile J.A., Said A.N., Sundstol, A.N.N) Agricultural Development Representative No. Ass Norway. 


\section{Cassava foliage as protein supplement for sheep}

Eore. C.V. 1973. Metabolism of dietary urea -1. cassava when used to supplement dry seawn roughages in Kenya. III World -nierence Animal Production Vol. 1:5c 2.45 .

Venedy, P.M. and Milligan, L.P. 1988. The degradation and utilization of endogenous urea in the gastro intestinal tract of ruminants. A review Journal Animal Science 60:205-221).

Lefadeju, E.A. 1988a. Evaluation of methods of improving utilization of mature Andropogon gayames hay by FreisianBunaji heifers. Ph.D Thesis ABU, Zaria. Pp $78-80$.

Mehrez, A.A. and Orskov, E.R. 1977. A study of the artifical fibre bag technique for determining the digestibility of foed in the rumen. Journal Agricultural Science (Camb) 88: $645-650$.

Mohammed, T.A., El-tayeb, A.E., Mustapha, A.F. and Khogali, H.M. 1987. Processed and unprocessed sorghum stover in Beef finishing rations, In overcoming constraints to eflicient utilization of agricultural by-products as animal feeds (Edited by Said A.N and Drowcla,B) ARNAB Ethiopia p $334-343$.

Moran, J.B., Saloto, K.B. and Dawson, J.E. 1984. Utilisation of rice straw fed to Zebu cattle and swamp buffalo as influenced by alkali treatment and leucaena supplement. Australian Journal of Agricultural Research. 34:73 - 84.
Ndlovu, L.R. and Buchanan-Smith, J.G. 1985. Utilisation of poor quality roughages by shoep: Effects of alfaalf supplementation on ruminal parameters, fibre digestion and rate of passage from the rumen. Canadian Joumal of Animal Science. 65: 673-703.

Ndlovu, L.R. 1985, Complimentarity of forages in ruminant digestion, theoretical consideration. In the complementarity of feed resources for animal production in Africa. Procecdings of the joint feed resoures network workshop held at Garbornoe Botswana pp 17 - 29.(Ed John, E.S., Said, A.D. and Jackson, A.K).

Nour, A.M. 1987. Rice straw and rice hulls in feeding ruminants in Egypt. In utilization of agricultural by-products as livestock feed in Africa. Proceeding workshop. Blantyre, Malawi (ARNAB).

Orskov, E.R. and McDonald, I. 1979. The estimation of protein degradation in the rumen from incubation measurements weighed according to rates of passage. Journal of Agricultural Science Camb. Vol. $92: 499-503$.

Silva, A. and Orskov, E.R. 1985. Effect of unmolassed sugar beet pulp on rate of straw degradation in the rumen of sheep given barelyt straw. Proceedings of the nutrition society, $44-50 \mathrm{~A}$.

Smith, O.B., Idowu, V.O. and Oduulumo, M.O. 1988. Comparative rumen degradability of forage browse, crop residues and by products. In: Wilson R.T and Azeb, M.(Eds) African Small Ruminants Research and development. P $204-208$. 


\section{Alli-Balogun, Lakpini, Alawa, Mohammed and Nwanta}

Smith, O.B. 1992. A review of ruminant responses to cassava based diets. In cassava as livestock feed in Africa. Proceedings of the IITA/IICA/University of Ibadan Workshop on potential utilization of cassava as a livestock feed in Africa. Pp 39-53.
Snedecor, G.W. and Cockran. XG.

Statistical methods IOWA State "io

Press Ames IOWA U.S.A.

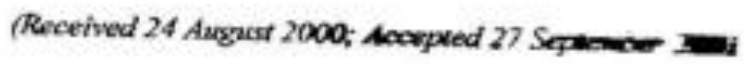

